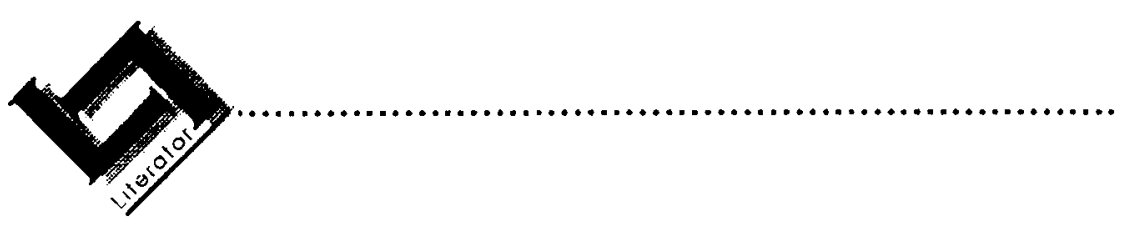

\title{
Die skryf van kabaret- en liedtekste: Enkele praktiese wenke ${ }^{1}$
}

\section{Hennie Aucamp}

'n Werkwinkelsessie oor die skryf van kabaret mag nie verval in akademiese spekulasies nie, maar as jy wenke puntsgewyse wil deurgee, soos ek nou gaan doen, kan dit weer maklik lyk of die spreker voorskriftelik wil wees. Ek wil dus nadruklik sè - hier in my eerste paragraaf - dat ek bloot wenke en suggesties wil deurgee, afgelei uit navorsing en uit my eie praktyk, wat uiteraard beperk is - vier en 'n half kabarette tot op hede: Met permissie gesê, Liefde onder lede, Slegs vir almal, Blomtyd is bloeityd en Oudisie! Tydens 'n besoek aan NALN 'n paar jaar gelede, sien ek 'n oorspronklike plakkaat, ontwerp deur Marjorie van Heerden, vir 'n kabaret wat lank gelede deur haar skoonma, Marie van Heerden, aangebied is in Die Oude Libertas-teater in Stellenbosch. Dit het Vlugsout geheet, maar ek kan weinig omtrent daardie kabaret onthou. Ek dink die program het uit 'n paar van my kortverhale bestaan, met liedjies as bindmiddels tussenin. Dis waarskynlik die program waar my samewerking met die komponis Jannie Hofmeyr begin het. Liefde onder lede, aangebied deur die Akademiespelers, was 'n kruis tussen legitieme teater en kabaret, en geld dus as 'n halwe kabaret.

Hoekom dié lang opsomming van my kabaretaktiwiteite? Net om te sê: eers praktyk, dan teorie. Wat natuurlik 'n halwe waarheid is, want soos reeds gemeld, het ek talle idees in boeke gekry, bowenal dié van Lisa Appignanesi en Wim Ibo. Geleidelik het ek 'n eie filosofie en struktuur vir

1 Hierdie artikel is ' $n$ verwerkte weergawe van ' $n$ praatjie wat aanvanklik gelewer is tydens 'n slypskoolsessie oor kabaret gereël deur die Dept. Kommunikasiekunde van RAU (22 Oktober 1994). Die ander deelnemers aan dié sessie was mnr. Coenie de Villiers, komponis en liedteksskrywer, en mnr. Stephan Bouwer, bekende kabaretregisseur en -kundige. Die teks van die oorspronklike praatjie is ook gepubliseer in Klasgids: 7-9, Oktober 1995. 
my kabarette gevind - 'n filosofie en struktuur wat my temperament pas, en dalk totaal onbruikbaar mag wees vir ' $n$ ander kabaretskrywer.

\section{Oorkoepelende temas}

Dit help om met oorkoepelende temas te werk. Vir my eerste kabaret, Met permissie gesê, was daar nie juis 'n saambindende tema nie, al het sake van die dag, soos die grensoorlogsituasie en kleurspanninge, prominensie gekry. Die eenakter, "Janblom dans 'n masurka", behoort in Papawerwyn en ander verbee/dings vir die verhoog te staan, maar ek het dit vir Met permissie "geleen". Die eenakter was 'n groot sukses, maar dit het die balans van Met permissie gesê versteur, sy sosiale satire ten spyt. Dit het gewoon te veel programtyd opgeëis.

Eintlik is 'n kabaret ' $n$ koorddanstoertjie. Jy wil nie aan die program die sfeer van 'n reeks solistiese nommers á la Ons hou konsert gee nie, maar daar moet tog 'n billike verdeling tussen items wees wat tydsduur betref. Dis hier waar 'n oorkoepelende tema van nut kan wees.

My tweede gepubliseerde kabaret, Slegs vir almal, het 'n ondertitel: "n kabaret oor selfsug".

Daar is ook onderverdelings binne Slegs vir almal - byvoorbeeld individuele selfsug teenoor groepselfsug (laasgenoemde op sy sterkste in politieke selfsug). Hierdie onderverdelings is by wyse van sekwense aangebied. Ek bespreek kortliks een sekwens, getiteld "Stank en dank", wat uit drie aaneenskakelende nommers bestaan.

Dié sekwens begin met 'n rou monoloog, "Die stank". 'n Psigopatiesgeneigde karakter bely aan ' $n$ veronderstelde hoorder in Joubertpark sy Afrikanerskap, en vertel hoe hy een aand deur 'n swart man gevolg is, kennelik met seksuele bybedoelings. In die skaduwee van die Kunsgalery volg 'n politieke konfrontasie, wat daarop uitloop dat die verteller die swart man doodsteek. Hierna bly sy moordwapen - 'n mes stink, hoe hy dit ook al mag was en ontsmet.

Uit dié monoloog volg 'n sedeles. Meer karakters sluit aan by die psigopaat in die park. Almal ruik 'n stank en kyk beskuldigend na mekaar, maar bly onseker. Later soek hulle die bron van die stank by die gehoor. Wat dié mime-toneel wil sê, is dat die mens - héél menslik geneig is tot skuldverplasing. Die korrektief op dié dwaling is ' $n$ lied wat "Übermensch" heet, en klink só:

Die stank wat jy ruik, mag jy self wees

al vee jy gereeld voor jou deur!

Steek liewers jou hand in jou boesem, 
kry die Übermensch onder beheer!

Maak gou, want die tyd raak al minder:

ook stank - soos 'n bom - kan verteer!

Die slotnommer in dié sekwens belig die boodskap vervat in die lied op 'n negatiewe manier. 'n Tipiese Afrikanervolksmoeder sing "Maar een Suid-Afrika", waarin sy die snelveranderende Suid-Afrika betreur. Haar dogter en seun wyk af van tipiese volksverwagtings. Die dogter, 'n rekenaarstudent, verwag; die seun het 'n verhouding met 'n donker meisie. Die titel van die lied wek natuurlik herinneringe aan die patriotiese gedig, "Maar een Suid-Afrika", van A.D. Keet, maar gaan reëlreg teen Keet se teks in, wat 'n tweespalt veroorsaak; ' $n$ breuk by wyse van ironie.

Die sekwense in Slegs vir almal is in 'n bepaalde volgorde geplaas, maar die praktyk het my geleer dat geen regisseur hom kan/wil hou by dié volgorde nie. Praktiese oorwegings, soos die beskikbaarheid van 'n bepaalde speler op 'n bepaalde oomblik, asook programbou vanuit show biz-perspektief, bring met elke opvoering nuwe strukture tot stand. Wat die program op die ou end "bind", is dus oorwegend sy oorkoepelende tema.

Regisseurs eerbiedig wel sekwense, en dis troos genoeg vir hierdie skrywer. Uit die aangehaalde sekwens, "Stank en dank", sou wel geblyk het dat daar ' $n$ mini-argumentasie in die spel is wat 'n eie onomstootlike gang het.

\section{Monoloë en dialoë}

Die soort item wat benut kan word, sluit al die ou strydrosse in: monoloë en dialoë (wat ook "sketse" genoem kan word); mime-nommers; skaduteater; marionettenommers; liedere (hetsy solo's of koornommers); danstonele.

Wat monoloë en dialoë betref, kan ek 'n paar wenke deurgee wat ek op die harde manier, dit wil sê via die praktyk geleer het. Die groot waarheid hier - die bottom line - is die volgende: kort is nog nie kort genoeg nie. As kortverhaalskrywer het ek gedink dat 'n monoloog van een-en-'n-half na twee bladsye kort is, maar die praktyk het uitgewys dat selfs 'n bladsy baie lank kan wees vir 'n speler en 'n gehoor. Met die monoloog "Die laaste soldaat" in Oudisie! het ek my teruggedwing tot ' $n$ halfbladsy.

Natuurlik speel die ervarenheid van die speler én die soort gehoor 'n rol.. Ruth Draper se beroemde monoloë is nie só kort nie, maar sy het hulle vir haarself geskryf, en kon elke sillabe met haar genialiteit besiel. 
'n Beter model vir die beginner-kabaretskrywer sou wees die beroemde Münchense kunstenaar, Karl Valentin. Hy het saam met sy vrou, Lise Karlstadt, opgetree - hy, lank en spigtig, byna insektaries; sy, teenoor hom gestel, belaglik kort. 'n Klassieke onpaar-paar, soos van Plautus se dae af.

Valentin se monoloë en dialoë is kort; van die halfbladsy- en een bladsysoort wat lengte betref. Tog tref hulle jou nie altyd as só kort op die verhoog nie, want hulle laat - veral binne dialoë - speling vir stiltes. Die stiltes van vertwyfeling en misverstand, want Valentin se onfeilbare suksesresep is om mense by mekaar te laat verbypraat.

Die skrywer van monoloë en dialoë moet 'n baie duidelike beeld hê van sy karakters: hul ouderdom, hul agtergrond, hul sosiale status, hul persoonlike hebbelikhede en persoonlike spreektaalritmes. Ek het studente, as 'n praktiese inleiding tot 'n dramakursus, dialoë rondom 'n tema laat skryf, maar eers moes hulle 'n volledige skets van elke karakter skryf. Op dié manier kon hulle toets of hul dialoë sielkundig klop met die verwagtings wat hul karaktersketse geskep het. Wat jy uiteindelik op die verhoog hoor, is die puntjie van die spreekwoordelike ysberg.

Dié metode het sy eie slaggate. Die gehoor het nie kennis van jou voorafgaande karaktersketse nie, en mag jou dialoog dalk as té gekonsentreerd, selfs kripties ervaar.

Wat myself betref, het ek die metode van karakterskets-as-leiding selde gebruik, en dit ook net as klaskameroefening. Ek het alles wat ek van studente verwag het, self gedoen. Die skets "Muurblomme" in Blomtyd is bloeityd is die neerslag van 'n dergelike oefening.

In die praktyk het ek van werklike situasies vertrek: die betrokke karakter, of dit nou 'n boemelvrou, ' $n$ prostituut of 'n parkswerwer is, was die heel tyd duidelik voor my. Die half psigopatiese karakter in "Die stank" gaan terug na 'n werklike man met wie ek in Joubertpark gesels het. Sy verhaal het my so geboei en ontstel dat ek val-val van haastigheid terug is na die Johannesburger, waar ek sy verhaal sommer op hotelpapier gaan neerskryf het; in sy eie woorde en ritme, in soverre ek dié dinge kon herskep het.

En nou moet ek op nog 'n slaggat wys: monoloë en dialoë is nooit blote bandtranskripsies nie. Die hand van ' $n$ organiseerder is nodig om ' $n$ gesprek toneelmatig te kry. Die kabaretskrywer - soos alle ander skrywers - selekteer, vul aan, verhewig. Soms gebruik jy deurentyd die werklike woorde van 'n karakter, maar spelers, gehoor en uiteindelike lesers mag sekere woorde en sinsnedes as vals aanvoel. "So 'n karakter 
sal nooit so iets kon gesê het nie", sê jou kritici soms kwaai. Dit help nie om kwaad te word vir jou kritici nie. Wat hulle as vals en ongeloofwaardig aanvoel, mag die resepsie van jou teks nadelig beïnvloed. Beweeg dus maar versigtig nader aan wat algemeen as "tipies" en "waar" aanvaar word.

Ek het al by talle geleenthede gesê dat Kaapstad my kabarette vir my skryf - sy parke, kroeë, klubs, strande, stasies. Ek moet hier 'n waarskuwing rig - aan myself, net so seer as aan voornemende kabaretskrywers, en dié waarskuwing is dat jy bloot met pittoreske tipes vorendag mag kom, en die lewens van misdeeldes en agtergeblewenes mag romantiseer. As jou skets nie sterk eksistensiële momente en insigte bevat nie, is jy dus besig om gerieflike clichés te bestendig. Die monoloog "Die stank" is hier 'n toetsgeval. My parkkarakter het teen die einde van sy storie hortend en onwillig begin huil, iets wat daarop dui dat hy, sy rassisme en selfregverdigings ten spyt, tog iets soos 'n gewete het - rudimentêr of sluimerend, maar tóg daar.

Teenoor hom gestel, het die volksmoeder, wat uit ' $n$ ander, en vermoedelik hoër sosiale stand kom, nie die minste gewetenswroeging oor haar rassisme nie. Die monoloog van die parkkarakter en die lied van die volksmoeder lewer as 't ware kommentaar op mekaar.

\section{Oor die skryf van liedtekste}

Oor die skryf van liedtekste wil ek my nie uitlaat nie - Coenie de Villiers, wat die musiek én woorde van sy liedere skryf, kan met veel meer gesag oor dié saak praat. Hy weet aan die lyf wat die Ink Spots bedoel wanneer hulle sing:

What good is a song

if the words just don't belong

Die liedteks het talle slaggate wat woorde en lied van mekaar kan vervreem. Ek noem net enkeles:

\section{- Die verledetydsvorm in Afrikaans}

Die verledetydsvorm in Afrikaans met sy "het ge"-konstruksies skep veral ritmiese probleme. Probeer jou lied - veral as dit verhalend is - in die historiese praesens hou.

\section{- Die dubbele negatief in Afrikaans}

'n Verdere jakkals wat die wingerd kan verniel, is die dubbele negatief in Afrikaans: nie ... nie; geen ... nie, ensovoorts. Selfs Van Wyk Louw het nie altyd raad geweet met die tweede negatiewe partikel nie, en het dit 
dikwels weggelaat in sy poësie. In dié opsig sluit hy aan by spreektaalen streektaalgebruike. Die Vorsters van Predikantskop, Jamestown, het byvoorbeeld konsekwent die tweede nie weggelaat - en John en Koot was gedugte orators. Die liedteksskrywer word egter klaar van digterlike onmag verdink, en moet dus 'n ander uitweg soek. My persoonlike uitweg is om 'n negatiewe stelling positief te stel. Ek sou liewers prontuit sê: "Sy is lelik" eerder as om te sê: "Sy is nie mooi nie". (Wat rym met "lelik" - "gemelik"?)

\section{- Onvoorsiene opposisies}

Onvoorsiene opposisies kan opduik in die teks, klank- en leestekengewyse. Wenk: laat 'n sanger jou lied sing voordat jy dit finaliseer. Amanda Strydom het my vertaling van "Waar is al die blomme heen" voortreflik gesing, maar sy moes in die proses my foute doodsing. Ek het byvoorbeeld geskryf: "Sê my waar is vader, kind?" wat 'n stommiteit was: jy hoor nie daardie komma nie, of as jy dit hoor, versteur dit die melodiese lyn. Latere vertolkers van dié lied het die voordeel van 'n vereenvoudigde weergawe. Hulle sing nou: "Sê my waar is pa en seun?"

Onthou die heel tyd dat jy 'n lied skryf vir die oor, en nie vir die oog nie.

In Eitemal se bekende "Die bootjie na Kammaland" is daar byvoorbeeld 'n reël wat só op papier lyk:

Hoe sag gly ons bootjie

Wat die oor hoor, is een van twee moontlikhede:

Hoe sa gly ons bootjie

of

Hoe sag ly/lei ons bootjie

Vermy, waar dit moontlik is, om 'n woord op 'n bepaalde klank te laat eindig - $-g$ in die geval van Eitemal - en die volgende woord op dieselfde klank te laat begin. Versmelting tot een klank is die gevolg, wat die oorspronklike betekenis van die reël kan verwring.

\section{- Skryf vir die oor}

My stelreël, "Skryf vir die oor", het wyer implikasies as net die individuele vasvalplekke wat klankkombinasies betref. Die hele teks moet onmiddellik toeganklik wees. Die gehoor voor jou het selde 'n teks voor hulle: wat jy sê, moet dus begryplik wees. Selfs eenvoudige reëls word nie altyd gehoor nie, en sommige van hierdie eenvoudige reëls mag die kernmededeling van jou lied wees. Herhaling in liedtekste is dus nie net 
'n musikale konvensie nie: dis 'n leerstrategie. Herhaling wil vaslê; vandaar, onder andere, die nut van refreine. By die tweede, derde herhaling besef 'n gehoor skielik: "Dis mos wat die man die heel tyd sê!"

\section{- Afrikaans is rymarm}

Daar word dikwels gesê dat Afrikaans rymarm is, en as digters soos Daniel Hugo en Stephan Bouwer dit sê, moet jy na hulle luister.

Ons wat liedtekste skryf, dink miskien meer basies oor ryme as digters. Ons skroom nie om rymwoordeboeke te raadpleeg nie. ' $n$ Rymdigter van faam, soos Philip de Vos, raadpleeg byvoorbeeld die Retrogade Woordeboek van prof. Johan Combrink, wat by die Universiteit van Stellenbosch in afgerolde vorm gekoop kan word. Cole Porter het gereeld rymwoordeboeke geraadpleeg, en Cole het liedtekste geskryf wat tot die poësieskat van 'n taal gereken kan word.

Luister maar na die begin van "Night and day":

Like the beat, beat, beat of the tom-tom;

when the jungle shadows fall,

Like the tick, tick, tock of the stately clock,

As it stands against the wall,

Like the drip, drip, drip of the raindrops,

When the Summer show'r is through,

So a voice within me keeps repeating

You - You - You.

Toe W.H. Auden liedtekste vir Benjamin Britten geskryf het, was onder andere Cole Porter sy model. Jammer genoeg het Auden se liedtekste iets van die selfbewustheid van 'n ernstige kunstenaar wat toegewings maak aan 'n populêre genre.

- Ritme: skering en inslag van die liedteks

Porter het gepraat van "the beat, beat, beat of the tom-tom": kyk nou hoe hy hom verder laat lei deur hierdie "beat". Ritme is skering en inslag van die liedteksbedryf.

'n Liedteksskrywer moet leer skandeer as dit nie deel van sy skoolopleiding was nie. Ook moet hy hom vergewis waar die klemme behoort te val in elke meerlettergrepige woord wat hy gebruik, en hiervoor is 'n doodgewone woordeboek al hulp genoeg.

Selfs 'n vakman soos Koos du Plessis het gesondig wat klemme betref. In die volgende reëls uit "Herman" 
Hul kom van ou oorde

waar ver winde waai

sou "ou", as dié reël natuurlik gelees word, klem moes kry; in gesonge vorm ignoreer Koos dié klem en skuif dit na "oorde" wat 'n verkeerde interpretasie van dié reël meebring.

Aan die begin van hierdie praatjie het ek dit sterk gestel dat ek wenke aanbied by die skryf van kabarette, en nie voorskrifte gee nie.

Maar wat elke skrywer, in watter medium ook al, moet onthou, is dat die retoriek van genres soos poësie en drama eeue en eeue oud is; 'n retoriek wat uit praktyk en teorie en filosofie gebore is. Wie die kennis, of kom ons sê prontuit die reëls, van eeue wil verbreek en aanpas, moet allereers dié reëls van buite ken, of die gevaar loop om as 'n charlatan afgeskryf te word.

Kernbegrippe:

kabaret

liedteks

Key concepts:

cabaret

lyrics 